\title{
The Role of Demography in the Transition to Sustainable Societies
}

\author{
Papel de la Demografía en la Transición a Sociedades Sostenibles
}

Amparo Vilches ${ }^{1}$

Daniel Gil-Pérez ${ }^{1}$

'Universitat de València' Departament de Didàctica de les Ciències Experimentals i Socials', Valencia, España. Corresponding author: amparo.vilches@uv.es

\begin{abstract}
Currently, although the global population has surpassed 7.5 billion and continues to increase in about 80 million each year, attention to demography is almost absent in most of the studies and publications related to the current situation of planetary emergency and the necessary transition to sustainable societies. For this reason, our first aim in this paper has been to discuss if this current lack of attention to demography is justified or not. With this purpose, we begin considering the scientific meaning of Sustainability, in order to overlay distorted and impoverish views of this concept that may hinder our study. Then, we analyse the reasons given by experts for and against the incidence of demographic growth in the current unsustainable situation of planetary emergency. Finally, we present proposals to face the ensemble of interconnected socio-environmental problems (including demographic evolution), to make possible an appropriate transition to sustainable societies.
\end{abstract}

Keywords: Demographic explosion; Demographic transition; Planetary emergency; Sustainable society; Sustainability.

Resumen: Aunque la población mundial ha sobrepasado los 7500 millones y continúa aumentando anualmente en alrededor de 80 millones, la atención a la demografía está hoy prácticamente ausente en la mayoría de los estudios y publicaciones acerca de la actual situación de emergencia planetaria y la necesidad de una transición a sociedades sostenibles. Con el propósito de analizar si esta falta de atención a la demografía está o no justificada, en esta contribución comenzamos discutiendo el significado científico de Sostenibilidad socioambiental, para evitar concepciones distorsionadas y empobrecidas de este concepto que pueden dificultar dicho análisis. A continuación estudiaremos las razones dadas por distintos expertos a favor y en contra de la incidencia del crecimiento demográfico en la insostenible situación actual de emergencia planetaria. Finalmente presentamos propuestas para hacer frente al conjunto de problemas estrechamente interconectados - incluido el problema demográfico - que caracterizan dicha situación, para hacer así posible una adecuada transición a sociedades sostenibles.

Palabras clave: Explosión demográfica; Transición demográfica; Emergencia planetaria; Sociedad sostenible; Sostenibilidad.

Received: 29 October 2018

Accepted: 24 July 2019 


\section{Introduction: What has to be Understood by Sustainability?}

Studying the relationship between demography - or any other subject - and Sustainability requires, first of all, avoiding what the President of the Worldwatch Institute, Robert Engelman (ENGELMAN, 2013, p. 3) has called "Sustainababble" ("[...] a cacophonous profusion of uses of the word sustainable to mean anything from environmentally better to cool. [...]"). It is necessary, in other words, to differentiate the new concepts of Sustainability and Sustainable Development (SD) from the ordinary use of these words, with meanings often opposed to the scientific concepts.

We must remember that the concept of Sustainability emerged as a result of many concordant scientific analyses of the severe socio-environmental problems that characterize the current planetary situation, such as, among others: depletion of natural resources, environmental pollution, climate change, destruction of biological diversity, disordered and speculative urbanisation, ecosystem degradation, inacceptable social inequalities (with a fifth of the human population suffering extreme poverty, while another fifth practices over-consumption), and conflicts and violence associated with these inequalities and the imposition of private interests and values against general welfare.

These problems are strongly interconnected and enhance mutually (DIAMOND, 2005), provoking an unsustainable situation of "planetary emergency" which seriously menaces the future of humankind (BYBEE, 1991).

The study of how to treat this current unsustainable situation gave origin to the definition, given by the World Commission on Environment and Development (WCED), of Sustainable Development (SD) in its report "Our Common Future" (WORLD COMMISSION ON ENVIRONMENT AND DEVELOPMENT, 1987, p. 16): “[...] a development that meets the needs of the present without compromising the ability of future generations to meet their own needs".

Many authors have insisted in the necessity of overlaying distorted and impoverish views of the new concept of Sustainability. We shall refer, given the interest of his contributions, to the Nobel price Murray Gell-Mann, who asked in Visions of a sustainable world (GELL-MANN, 1992) "What do we mean by 'sustainable'?" This was his clarifying answer:

Surely we do not mean stagnation, with no hope of improvement in the lives of hungry or oppressed human beings. But neither do we mean continued growing abuse of the environment as population increases, as the poor try to raise their standard of living, and as the wealthy exert an enormous per-capita environmental impact. [...] The literal meaning of the word 'sustainable' is not useful here. For example, complete absence of life or of human life might be sustainable for a long time, but it is not what we mean. Universal tyranny might be sustainable, but that is not what we mean either. [...] The key concept is probably the achievement of sustainable quality, quality not purchased mainly at the expense of the future. It encompasses quality of human life and quality of the biosphere, including survival of many of the organisms with which we share the planet and the ecological systems that they form. (GELL-MANN, 1992, p.5). 
"We have a growing multiplicity of environmental problems" - adds Gell-Mann (1992, p. 6) "affecting climate, the oceans, the quality of water and air, to say nothing of the disappearance of species and ecological systems, deforestation, desertification, soil erosion, and so on. Many of the problems are old, but the scale is new". And one of the reasons of this dangerous current situation, affirmed Gell-Mann in the same paper, is an explosive growth of human population that worsens many of these problems.

Was it justified to include the demographic growth among the problems to be contemplated for attaining Sustainability? Which were the reasons furnished by Gell-Mann and many other authors? And, why is not demography contemplated nowadays in most of the holistic studies about the necessary transition to sustainable societies? These are two of the questions that have oriented our study.

\section{Is Demographic Growth a Real Problem for Sustainability?}

As we have just highlighted, Gell-Mann (1992) considered demographic explosion as a problem that seriously aggravated the situation of planetary emergency. In fact, the number of human beings had been quite low during most of the history of our species and did not reach a billion until the beginning of the $19^{\text {th }}$ century, when a rapid increase of human population took place, mainly due to medical and sanitarian advances which drastically reduced the early death indexes. As a result, human population had surpassed 6 billion at the end of the $20^{\text {th }}$ century. As Gell-Mann $(1992$, p. 6) insisted,

\footnotetext{
[...] the rising curves of world population and natural-resource depletion cannot go on rising steeply forever; they must soon pass through inflection points. Will those curves flatten out as a result of human foresight and progress toward a sustainable world? Or will they turn down as a result of the traditional scourges of war, famine, and pestilence? If they do flatten out, will it be at levels that permit a reasonable quality of human life, including a measure of freedom, and the persistence of a large measure of biological diversity? Or will it be at levels that correspond, if there is a sustainable society at all, to a grey world of scarcity, pollution, and regimentation, with plants and animals restricted to a few species that co-exist with mankind?
}

This concern about demographic explosion has been shared by numerous experts at the end of the $20^{\text {th }}$ century and at the beginning of the $21^{\text {st }}$ century (BERG, 2018; DIAMOND, 2005; EHRLICH; EHRLICH, 1991; ENGELMAN, 2012; WORLD COMMISSION ON ENVIRONMENT AND DEVELOPMENT, 1987). We shall summarize the reasons given by these and other authors to justify their preoccupation about the role demographic growth can play, together with over-consumption and other socio-environmental problems, in the current unsustainable situation of planetary emergency:

- Throughout the $20^{\text {th }}$ century, human population almost quadruplicated and, although the rate of population growth has lately diminished, this population increases every year by about 80 million. As long ago as 1987, the World Commission on Environment and Development pointed out the consequences of this increase: "In many parts of the world, the population is growing at rates that cannot be sustained by available environmental resources, at rates that are outstripping any reasonable expectations of improvements in housing, health care, food security, or energy supplies" (WORLD COMMISSION ON ENVIRONMENT AND DEVELOPMENT, 1987, p. 18). And 30 years later 
Berg (2018, p. 1379) insists. "In 1968, the global population was about 3.5 billion; since then, the human population has more than doubled a rise that has been accompanied by largescale changes in land use, resource consumption, waste generation, and societal structures".

- According to Diamond, in 1986 it was estimated that

[...] humans then already used (e.g., for crops, tree plantations, and golf courses) or diverted or wasted (e.g., light falling on concrete roads and buildings) about half of the Earth's photosynthetic capacity. Given the rate of increase of human population, and especially of population impact, since 1986, we are projected to be utilizing most of the world's terrestrial photosynthetic capacity by the middle of this century. That is, most energy fixed from sunlight will be used for human purposes, and little will be left over to support the growth of natural plant communities, such as natural forests. (DIAMOND, 2005, p. 500).

- Another way of illustrating the danger humans represent for biological diversity has been given by Harary (2011, p. 73) in Sapiens: a brief history of humankind:

Today, the earth's continents are home to almost 7 billion Sapiens. If you took all these people and put them on a large set of scales, their combined mass would be about 300 million tons. If you then took all our domesticated farmyard animals cows, pigs, sheep and chickens - and put them on an even larger set of scales, their mass would amount to about 700 million tons. In contrast, the combined mass of all surviving large wild animals - from porcupines and penguins to elephant and whales - is less than 100 million tons.

- As expertsin Sustainability explainedat the Rio+5Forum, the existing human population in 1997 would need the resources of three Earths to generalise the standard of living of the developed countries. It is to say: our planet had not enough resources in 1997 to make this achievement possible. Today, with more than 7.5 billion human beings, the situation is logically worse. Even if the existing resources were better distributed, avoiding the current inacceptable inequalities, and people consumed, in average, quite less than wealthy people do nowadays, the whole population's footprint still would surpass the Earth's biocapacity. In other words: the existing human population exceeds, or will soon exceed, the carrying capacity of the Earth.

- According to recent studies, achieving the Sustainable Development Goals (SDGs), set by the United Nations (UN) in 2015 for the period up to 2030, would require to lower population growth even below the lower bound of recent UN probabilistic population projections (ABEL et al., 2016).

Facts and data such as those we have just summarized, led Ehrlich and Ehrlich (1991) to emphatically affirm that, without any doubt, the demographic explosion will soon stop. What we do not know, they added, is whether the end will arrive gently, through a decrease in the birth rate, or tragically, through the growth of mortality. These authors concluded that demography is the most serious problem humanity has to face today, given the time gap between the start of an appropriate programme and the beginning of population decline.

Diamond (2005) has rejected this tendency to designate "the most serious problem" humanity has to face: demographic growth, as Ehrlich and Ehrlich (1991) did at the end of the $20^{\text {th }}$ century, climate change, as many do nowadays, or any other (accelerated loss of biodiversity, hunger and extreme poverty of billions of human beings, etc.). 
In his book Collapse: how societies choose to fail or succeed, Diamond shows that the sudden collapse of some isolated societies - such as the Amerindian Anasazi's culture - was associated to a dozen of problems, including human population growth, of course, but together with other problems such as resources depletion, pollution, or conflicts and violence. And the most interesting fact of his analysis is to have shown that these problems are linked:

[...] one problem exacerbates another or makes its solution more difficult. For example, human population growth affects all 11 other problems: more people means more deforestation, more toxic chemicals, more demand for wild fish, etc. [...] any of the dozen problems if unsolved would do us grave harm, and because they all interact with each other. (DIAMOND, 2005, p. 505, 507).

In other words: none of the problems is "more important" than the others, because none can be solved in isolation: it is necessary to take into account the ensemble of interconnected problems. Nevertheless, Diamond's conclusion is very similar to that of Ehrlich and Ehrlich (1991):

[...] the world's environmental problems will get resolved, in one way or another, within the lifetimes of the children and young adults alive today. The only question is whether they will become resolved in pleasant ways of our own choice, or in unpleasant ways not of our choice, such as warfare, genocide, starvation, disease epidemics, and collapses of societies. While all of those grim phenomena have been endemic to humanity throughout our history, their frequency increases with environmental degradation, population pressure, and the resulting poverty and political instability. (DIAMOD, 2005, p. 507, emphasis added by author).

The main challenge of the $21^{\text {st }}$ century - affirms Sachs $(2003$, p. 3 ) in Common wealth: economics for a crowded planet - will be "[...] protecting the environment, stabilizing the world's population, narrowing the gaps between rich and poor, and ending extreme poverty".

Brown and Mitchell (1998) summarised the question at the end of the $21^{\text {st }}$ century by saying that population stabilisation is a fundamental requirement to halt the destruction of natural resources and guarantee the fulfilment of everyone's basic needs. In other words: a sustainable society is a society demographically stable. But we find nowadays many authors who consider that the problem is just the opposite: the decline of human fertility level. We shall study and discuss their reasoning in the next section.

\section{Current Attention to the Role of Demographic Growth in Sustainability}

The concern of many experts about population growth that we have summarized, contrasts with the current lack of attention to this problem among educators and researchers on Sustainability.

We have repeatedly confirmed the lack of attention to demography among science teachers in both service and training. Effectively, in order to ascertain the extent to which science education adequately approaches the state of the world, at the beginning of this century we have put an open question, about problems and challenges that humanity has to face, to a total of 327 teachers in service and 521 in training participating in science education courses we have given in Spain, Portugal and Latin America (Argentina, Brazil, Chile, Cuba, Mexico and Panama). Only 17.7\% (SD 1.7) of teachers in training and $20.5 \%$ (SD 2.2) 
of teachers in service have made any reference to demographic problems, while, for instance, environmental pollution or depletion of natural resources were mentioned at much higher percentages (GIL-PÉREZ et al., 2003; MARQUEZ et al., 2008). We have repeated the question in 2017 with quite similar results: out of the 126 science teachers in training consulted, only 22.2\% (SD 3.7) mentioned the demographic problem.

And which is the attention given to demography by researchers on Sustainability? As Engelman (2009) points out, "in the U.S., this discussion remains muted. [...] You are more likely to read about population growth in a letter to the editor than in a news story or editorial". Bryant et al. (2009, p. 852) insist in regretting this scarce attention to demography: "The links between rapid population growth and concerns regarding climate change have received little attention".

It is also surprising the absence of references to demography in studies about planetary boundaries. As Folke (2013, p. 22) states, the planetary boundaries "[...] describe an envelope for a safe operating space for humanity that, if respected, would likely ensure that Earth remains in a Holocene-like state". Nine are the planetary boundaries enumerated: Climate change, Rate of biodiversity loss, Nitrogen and Phosphorous cycles, Stratospheric ozone depletion, Ocean acidification, Global freshwater use, Change in land use, Atmospheric aerosol loading, and Chemical pollution. And, although Folke (2013, p. 26) recognizes that "planetary boundaries are interdependent, because crossing one of them may shift the position of other boundaries or cause them to be transgressed", nothing is said about the logical link between, for instance, "global freshwater use" and the population dimension and consumption levels.

This lack of attention affects even the 17 Sustainable Development Goals (SDG) and 169 targets established by UN in 2015 for making possible the transition to sustainable societies. None of them refers explicitly to population growth. In the final version of SDG, the Goal 3 (Ensure healthy lives and promote well-being for all at all ages) only includes an indirect reference in target 3.7: "By 2030, ensure universal access to sexual and reproductive healthcare services, including for family planning, information and education, and the integration of reproductive health into national strategies and programmes" (UNITED NATIONS, 2020). A precedent version of the SDG was much more explicit: its Goal 2 was Achieve development within planetary boundaries. All countries have a right to development that respects planetary boundaries, ensures sustainable production and consumption patterns, and helps to stabilize the global population by mid-century. And its target 2c. stated: "Rapid voluntary reduction of fertility through the realization of sexual and reproductive health rights in countries with total fertility rates above 3 children per woman and a continuation of voluntary fertility reductions in countries where total fertility rates are above replacement level" (COUNCIL OF THE SUSTAINABLE DEVELOPMENT SOLUTIONS NETWORK, 2013, p. 28). Changes introduced in the final version may be due to the existence of a strong social resistance - particularly because of political and religious prejudices - to accept that a growing population poses a serious problem. This resistance has been detected, for instance, by Weiss (2016, p. 39): "[...] population has become a taboo topic - often avoided, if not intentionally ignored - in peerreviewed literature, scientific conferences, and academic discussions".

Particularly surprising is the absence of references to demography in the field of Sustainability Science, an interdisciplinary and transdisciplinary scientific domain created at the beginning of the $21^{\text {st }}$ century with the explicit aim of carrying out a systemic treatment - without reductionisms - of the ensemble of problems that determine the current 
unsustainable Earth situation, until then studied by separated disciplines (CLARK, 2007; KATES et al., 2001; KOMIYAMA; TAKEUCHI, 2006; TAKEUCHI et al., 2017; VILCHES; GIL-PÉREZ, 2016a).

We have proceeded to analyse the papers published by the journal Sustainability Science ever since it came into being in 2006 to 2017, and those published by Sustainability, also from its inception in 2010 up to 2017, including issues dedicated to proceedings of several international sustainability conferences and selected papers of six World Sustainability Forum. In those hundreds of papers, we did not find any reference to the possible role of demography in the current and future Earth's situation. Obviously, we do not blame the journals for this absence: it responds to a current general tendency in society and in our scientific community.

We could think that this recent lack of attention to demography in Sustainability studies could be due to the fact of having entered in a new phase of "demographic transition" that would put an end to the danger of an explosive population growth. It is worthwhile, then, to analyse this transition.

We may illustrate what is known by demographic transition referring to what happened in Europe since the end of the $18^{\text {th }}$ century (OSTERHAMMEL, 2014): until this moment, each woman had, on the average, six children, but population hardly grew, because many of these children died, and adults were also affected by numerous illnesses that provoked early deaths. But, thanks to the improvement of life conditions due to the industrial revolution - and, we must not forget, the exploitation of colonies - such as a better nutrition and sanitation, as well as the invention of vaccination and other medical progresses, child mortality decreased and life expectancy increased; so, as couples continued having as many children as was usual, an explosive population growth took place. But once the fear of the frequent child mortality disappeared and, on the other hand, women joined to labour away from home, couples began to have fewer children, with the aid of effective family-planning methods to avoid non-desired pregnancies. Thanks to this, birth and death rates approached again, stopping the demographic explosion. However, during this demographic transition industrialised countries became over-populated and aged. Something similar is happening today in many other countries and, therefore, we can expect the interruption of the world population growth... but after the over-population of regions today less inhabited as the Sub-Saharan Africa.

Robinson (2013) has analysed these demographic changes and its consequences in his paper Population and sustainability. He begins reminding us that "During the past two decades, a dominant concern was that rapid global population growth, due to falling mortality and high fertility, would aggravate poverty, cause political instability, and overwhelm natural resources". Now, as the global increase appears to be slowing down thanks to rapid declines in fertility in many countries (although the world's population continues increasing), we could expect that analysts, policymakers and citizens in general could view the future more optimistically. What has happened has been quite different: journalists and commentators have begun to speak about the danger of a "population implosion", considered "[...] as ominous to our future social and economic orders as was the 'population bomb' several decades back" because of the "shrinking of labour force" Accordingly with this reasoning, there is a growing demand of policies that promote a higher fertility rate to maintain a sustainable proportion between active population and economically dependent groups. 
This intention of maintaining a proportion of 4 or 5 workers for each retired is an example of policy oriented by short term interests, without considering its future consequences: most of these 4 or 5 workers will arrive to the age to become retired, and this will demand to multiply the number of workers to sustain them... and so on. This is obviously unsustainable, even having recourse to immigration, because these immigrant workers will also become retired. In fact, this is a clear example of what is known as pyramid scheme fraud - condemned to produce, sooner or later, a global bankruptcy - and shows how narrow analyses, using partial data, lead to erroneous decisions.

As Engelman (2012, p. 127) explains, it is true that ending population growth would accelerate population aging, but we should try to

\begin{abstract}
[...] adjust to population aging rather than trying to delay it through governmental incentives or programs aimed at boosting childbearing [...] Even if today's policymakers could boost population growth through higher birth rates or immigration, future policymakers would have to grapple with the problems of aging at some later time.
\end{abstract}

We need a new demographic culture, as necessary for the transition to sustainable societies as the new energy culture or the new water culture: a demographic culture that facilitates the transformation of the traditional demographic pyramid, with much more young than aged people (unsustainable because it demands a permanent increase of population in a limited planet), into something close to a cylinder, with similar numbers of human beings in the different age groups.

On the other hand, which is the sense of this alarm over the empty workbench, when "Even as the size of the world economic product has more than tripled since 1990, securing adequate and decent employment for all jobseekers remains one of the biggest problems policy-makers face"? (POSCHEN, 2015, p. 1). The real problem today - and in the future that technological innovation and computerization are already designing - is the lack of jobs. No wonder if the International Labour Organization (ILO) is dedicating a significant part of its efforts to fight the growing unemployment mainly among young people - and to conceive policies of "decent work" for the transition to sustainable societies (POSCHEN, 2015). As a result, one of the Sustainable Development Goals that guide the world Sustainable Agenda 2015-2030 aims to "[...] achieve full and productive employment and decent work for all women and men, including for young people and persons with disabilities, and equal pay for work of equal value" (goal number 8) (UNITED NATIONS, 2020).

We shall come back to this fundamental Goal in a section dedicated to global considerations about the necessary Sustainability transition. But, before that, we have to refer to another serious obstacle for an appropriate treatment of the Demography-Sustainability relationship: the difficulties encountered in many countries for accessing to sexual education and social services needed to exert the human right to a responsible parenthood.

\title{
The Human Right to a Responsible Motherhood and Fatherhood
}

Today, when human population has surpassed 7.6 billion, slowing down the rise in human numbers is essential for the planet, but how can we achieve this goal? Engelman (2009) raises the essential question: "[...] are there measures that the public and policy makers would support that could actually bring about such a change?" 
Engelman (2009) reminds us the general logical rejection of compulsory "population control" over families and the strategy that 179 nations signed onto at a United Nation conference in Cairo in 1994: "forget population control and instead help every woman bear a child in good health when she wants one". That means to acknowledge the basic Human Right to determine how many children to have and when to have them, facilitating the necessary sexual education and social services to make it possible. This would be enough, explains Engelman (2009), because "More than 200 million women in developing countries are sexually active without effective modern contraception even though they do not want to be pregnant anytime soon, according to the Guttmacher Institute, a reproductive health research group. By the best estimates, some 80 million pregnancies around the world are unintended", a similar number to the current world population growth every year. The Guttmacher Institute has shown that, even in USA, 45 percent of all pregnancies are unplanned (ENGELMAN, 2016; FINER; ZOLNA, 2016).

In 1989, World Population Day was instituted to reaffirm the human right to plan for a family, and to build an awareness of population issues and the impact they have on development and on the environment, in order to reduce our environmental footprint. Despite initiatives like this one, modern contraception remains out of reach for millions of women, men and young people, for reasons ranging from lack of access to information or services to lack of support from their partners or communities.

The United Nations Fund for Population Activities (UNFPA) dedicates all its efforts to combat this serious problem. Its report State of world population 2012, for instance, was dedicated to "by choice, not by chance", drawing attention to the high rates of unintended and unwanted pregnancies in both developing and developed countries. And the State of world population 2018 report is entitled The power of choice: reproductive rights and the demographic transition. (KOLLODGE, 2018).

A very serious barrier for recognizing the human right to a responsible parenthood and for enjoying sexuality independently of procreation is, undoubtedly, the influence of many religious and cultural traditions in this domain. The biblical order "Populate the Earth abundantly and multiply in it" could have sense when human population was scarce and there was a danger of extinction, but nowadays we cannot ignore the impossibility of a continuous demographic growth in a limited planet. Nevertheless, some churches continue "recommending abstinence as the preferred behaviour for avoiding unintended pregnancy" (ENGELMAN; TAREFE, 2016), and the recent encyclical Laudato Si, published in 2015 (FRANCIS, 2015), absolutely rejects the voluntary interruptions of pregnancy and even the experimentations with embryos. We shall reproduce some items of the encyclical that illustrate this rejection. In its item 50 we can read:

[...] while it is true that an unequal distribution of the population and of available resources creates obstacles to development and a sustainable use of the environment, it must nonetheless be recognized that demographic growth is fully compatible with an integral and shared development. (FRANCIS, 2015, p. 35).

In item 120:

Since everything is interrelated, concern for the protection of nature is also incompatible with the justification of abortion. How can we genuinely teach the importance of concern for other vulnerable beings, however troublesome or inconvenient they may be, if we fail to protect a human embryo, even when its presence is uncomfortable and creates difficulties? (FRANCIS, 2015, p. 89). 
And in item 136:

[...] it is troubling that, when some ecological movements defend the integrity of the environment, rightly demanding that certain limits be imposed on scientific research, they sometimes fail to apply those same principles to human life. There is a tendency to justify transgressing all boundaries when experimentation is carried out on living human embryos. We forget that the inalienable worth of a human being transcends his or her degree of development. In the same way, when technology disregards the great ethical principles, it ends up considering any practice whatsoever as licit. (FRANCIS, 2015, p. 101).

We do not believe that medical abortions and experimentation with embryos "disregards the great ethical principles". On the contrary, these actions are founded in deep ethical considerations: the cells that constitute the embryo are initially the same cells present, separately, in spermatozoids and ovules, and they do not abruptly become, in the moment of fecundation, human beings with suffering and enjoying capacity. Who actually suffer are women pregnant against their wish. And ethical principles based in Human Rights urge us to help them, eradicating legislative and educational barriers against the erroneously called contraceptive or birth-control methods, in order to make possible a satisfactory affective and sexual life and a responsible parenthood, both from a familiar and a social point of view, given the influence of demography on the situation of planetary emergency. We need sexual education and social services to make possible pregnancies "by choice, not by chance".

We may conclude that - in spite of strong resistances such as some religious traditions - demography certainly influences the current unsustainable situation of human societies and the whole biosphere. Therefore, its study must be reincorporated as one of the related factors that affect this situation, overcoming the insufficient attention given nowadays to the Demography-Sustainability relationship (ENGELMAN, 2009).

\section{An Appropriate Treatment of the Demography-Sustainability Relationship}

As we have already pointed out in section 2, we face a serious contradiction about the Demography-Sustainability relationship. On the one hand, it has been well established that population is "[...] a major driving force for environmentally damaging emissions, impacts, or resource consumption" (KATES; PARRIS, 2003, p. 8062). Consequently, "[...] slowing the rise in human numbers is essential for the planet" (ENGELMAN, 2009). But, on the other hand, ending population growth would accelerate population aging, causing the fall of the economically active share of the population, while the economically dependent share increases (ROBINSON, 2013). Should childbearing be indefinitely incentivized for this reason? This has no sense, of course, in a limited planet. As Engelman (2012) concludes, we should try to adjust to population aging rather than trying to delay it through governmental incentives. In fact, countries like Japan, South Korea or Germany that are already facing populations aging have begun to invest in advanced robotic technology to meet their labour needs (CHAMIE, 2017). In any case, problems caused by population aging must be faced, but they are smaller than those created by the continuous population growth - something absolutely unsustainable - or even by its stabilisation in a too high number. Summing up, a sustainable welfare of the ensemble of human beings requires that the demographic transition finishes soon, stabilising population - voluntarily, but without hindering barriers - in numbers no much 
higher than the currents ones. Advances towards this aim are studied and promoted nowadays, for instance, by the Family planning and environmental sustainability assessment project (ENGELMAN et al., 2016).

Nonetheless, we have to remember that this demographic transition, although indispensable, is absolutely insufficient, because the demographic problem is linked to many other problems creating a complex and unsustainable situation of planetary emergency that has to be globally treated to make possible the transition to sustainable societies.

\section{The Many Requisites for the Necessary Transition to Sustainable Societies}

Transition to Sustainability requires, as we have already pointed out, numerous and simultaneous transitions, in addition to the demographic one we are studying here. We may refer, in particular, to the following indispensable interconnected transitions:

- Transition to a responsible consumption, putting an end to predator-like overconsumption of many essential resources (fresh water, minerals, fertile soils, fishing banks...) as if the Earth's capacities were endless (DALY, 1991; WORLD COMMISSION ON ENVIRONMENT AND DEVELOPMENT, 1987). As Harari (2011, p. 424) writes in Brief history of humankind, "A lot of evidence indicates that we are destroying the foundations of human prosperity in an orgy of reckless consumptions";

- Transition to a circular economy, restorative and regenerative, aiming to keep products, components, and materials at their highest utility and value at all times in order to reduce resources depletion and avoid the continuous production of waste, responsible for a planetary pollution of lands, waters and air which is contributing to the degradation of all ecosystems, destruction of biological diversity, desertification... (GHISELLINI; CIALANI; ULCIATI, 2016);

- Energy transition from fossil resources to renewable, clean energy. "Shifting to renewable energy sources and alternative ways of life is the challenge of our time" (PRINCEN; MANNO; MARTIN, 2013, p. 161). Among many reasons for that transition, we may point out the necessity of stopping the emission of greenhouse gases, responsible for a climate change that is causing the fast loss of everlasting snows (the most important reservoir of fresh water for billions of human beings and many other species) and the increase of the frequency and intensity of extreme weather phenomena (hurricanes, floods, droughts, fires...) that are contributing to a degradation process of ecosystems that risks to become irreversible, making the Earth inhabitable for humans and other species;

- Urban transition, putting an end to the current accelerated and disordered urbanisation and the abandon of the rural world, with serious consequences (O'MEARA, 1999) such as: waste concentration and its polluting effects on soils and waters; air and sound pollution (due to traffic density, heating, etc.) with their respective consequences on respiratory diseases, stress...; destruction of agricultural soil; speculation and lack of planning, which leads to chaotic growth (illegal construction without the proper infrastructures), use of substandard materials, occupation of areas vulnerable to natural catastrophes...; more time and energy needed for commuting; separation from nature; social exclusion and citizen insecurity, which increases with cities' dimensions. The Worldwatch Institute (2016) dedicated The State of the World 2016 to the urban 
transition towards sustainable cities, contemplating the different challenges and possible solutions, with chapters dedicated to, among others, Reducing the Environmental Footprint of Buildings, Urban Transport and Climate Change, Supporting Sustainable Transportation, Source Reduction and Recycling of Waste, Rural-Urban Migration, Social Justice and Urban Planning for Diversity and Social Cohesion;

- Transition from an ethnocentrism depredatory of the rest of the biosphere to the recognition of the necessity of protecting biodiversity, putting an end to the current accelerated extinction of species that is threatening the survival of our own species (NORMANDER, 2012). For this reason, the extinction rate of biodiversity loss (number of species disappeared per million species per year) is considered as one of the most important planetary boundaries not to be surpassed. Its preindustrial value is estimated in the interval 0.1-1 and the proposed boundary is 10 , while the current value is superior to 100 (FOLKE, 2013);

- Transition from destruction to protection and impulse of cultural diversity. The loss of cultural diversity is connected to the exaltation of cultural forms (religious, ethnic...) considered to be superior or true, which leads to their imposition over others, generating social and political conflicts, movements of ethnic cleansing, opposition to linguistic pluralism and imposition by the culture industry, through mass media control, of impoverishing patterns which are generators of exclusion (GIL-PÉREZ et al., 2003).

Enrichment produced by cultural diversity should be emphasised, but without accepting "cultural expressions" which do not respect human rights as, for instance, women's sexual mutilation (MAALUF, 2009). We must not forget, above all, that cultural diversity guarantees a plurality of answers to the problems human societies have to face: each culture enriches all humanity and becomes a human heritage.

- Transition in Labour. A sustainable society requires the existence of proper employment for all jobseekers in order to avoid unacceptable disequilibria (POSCHEN, 2015). We may remember that Goal number 8, of the Sustainable Development Goals that guide the world Sustainable Agenda 2015-2030, aims to "[...] achieve full and productive employment and decent work for all women and men, including for young people and persons with disabilities, and equal pay for work of equal value" (UNITED NATIONS, 2020). But as techno-scientific innovation favors the suppression of many simple tasks and its corresponding employments (FREY; OSBORNE, 2017), new fields of employment are needed to satisfy citizens' fundamental rights and contribute to the transition to sustainable societies. These new possibilities of sustainable employment exist (VILCHES; GIL-PÉREZ, 2016b): we may mention, for instance, the development of renewal energies, ecological agriculture, ecosystems' protection and restoration, ecological building... without forgetting occupation aiming to guarantee a universal access to fundamental public services such as health or education and to enhance the culture production and diffusion as an alternative to the unsustainable high consumption of material goods (MAALUF, 2009).

- Transition from competitiveness to cooperation and universalization of Human Rights. It is unsustainable and ethically unacceptable the existence of extreme inequalities between different human groups, associated with the imposition of private interests and values (in particular of trans-national enterprises which seek to avoid any democratic 
control) that provoke conflicts and wars, with their arms races and destruction; class, interethnic and intercultural confrontations, which lead to terrorist behaviours in groups and states; mafia activities, trafficking with weapons, drugs and people, thereby contributing to violence; forced migrations of millions of people, worsened by climate change and the clashes between nations; risk of democratic retrogressions resulting in citizens' growing lack of interest in public issues. Therefore, planetary regulations are necessary in order to avoid a general socio-environmental degradation process. In other words: a new world order is required, based on cooperation and solidarity, with institutions capable of avoiding the imposition of particular vested interests harmful to other people or to future generations (SACHS, 2008). Achieving sustainable development is understood today as synonymous with universalising Human Rights in their widest sense and without any kind of discrimination (GIL-PÉREZ; VILCHES, 2017). This requires:

- The creation of democratic institutions, also at a planetary level, capable of putting an end to socioeconomic growth guided by private interests in the short term, which seriously damage the environment and are particularly dangerous to living beings;

- The orientation of scientific-technological development towards the attainment of technologies favourable to sustainable development;

- The promotion of an education capable of countering the usual tendency to behave on behalf of particular interests in the short term.

The ensemble of Human Rights appears to be a requisite (and, at the same time, an objective) of a sustainable society, as they are all interconnected. We cannot expect, for instance, that some people do not contribute to the depletion of a fishing bank... when this is their only resource to nourish their family. And we cannot conceive, to give another example, the interruption of the demographic explosion without the recognition of the right to family planning and free enjoyment of sexuality... and this is also linked to the right to education: as former Unesco's Director, Mayor Zaragoza (MAYOR; BINDE, 2000) stated, education for all is necessary to reduce the continuous growth of population in any religious or ideological context.

It is particularly necessary for individual and collective actions to avoid local or partial approaches and contemplate many-sided environmental questions (pollution, climate change, resources depletion...), and other related problems, such as social inequalities and conflicts, from a planetary perspective. The ecologists slogan to think globally and to act locally has its limitations, we now know that it is also necessary to act globally as well, by adopting measures on a "glocal" (global and local) scale (NOVO, 2006), capable of avoiding let us insist - the imposition of individual interests and values harmful for other people or for future generations.

Each one of the transitions we have summarized here are condition sine qua non for attaining Sustainability, because, as we have repeatedly stated, all of the correspondent problems they try to solve are interconnected and mutually affected through complex linkages. To forget or ignore one of them - as it is currently happening with demographic transition to a stable world population - may obstruct the other transitions and condemn human species and the whole biosphere to degradation. But this necessity of so many difficult transitions does not mean a limitation for human welfare. We shall dedicate our conclusions to this essential question. 


\section{Conclusions and Perspectives}

The necessary complex transition to Sustainability we have just described must not be contemplated as an obstacle towards the achievement of sustainable quality of life for the ensemble of world population and as a sacrifice for those that today enjoy a certain capacity of consumption and choice. On the contrary, as Amin Maaluf (MAALUF, 2009) explains, satisfactions linked to material overconsumption entail an unsustainable burden for the planet's resources and provoke inequalities and destructive tensions, while culture and knowledge are unlimited universes at our disposal that may give us deeper satisfactions than material consumption. We may learn languages or be passionate by different artistic and scientific subjects, without any danger of exhaustion. And we may reach an even higher satisfaction if we can participate in the elaboration of cultural products or in the solution of relevant problems, contributing to knowledge enlargement and improvement of sustainable life conditions for human beings and for the ensemble of the biosphere.

It is true that human activities have provoked dangerous changes in the Earth's Ecosystems (VITOUSEK et al., 1997) and in the physical systems of the planet. For this reason, the Nobel Prize Paul Crutzen has introduced the term Anthropocene to designate a new geological period in which the great changes suffered by the Earth - and more precisely by the biosphere - are due to human action (SACHS, 2008). But this new period also constitutes an opportunity to rethink human behavior to overcome the situation of planetary emergency and make possible a sustainable present and future. The Sustainable Development Goals (SDG), approved by the General Assembly of United Nations in 2015, have been conceived for this necessary transition to sustainable societies.

We shall finish recognizing that it is not easy to accomplish this transition to Sustainability, because it demands a deep transformation of the socioeconomic model, of our habits and, summing up, of our way of connecting with nature and with each other. It is not easy, but it is possible and urgently necessary to guarantee the continuity of our species and worthy living conditions for the ensemble of human beings.

\section{References}

ABEL, G. J.; BARAKAT, B.; SAMIR, K. C.; LUTZ, W. Meeting the sustainable development goals leads to lower world population growth. Proceedings of the National Academy of Sciences, Washington, v. 113, n. 50, p. 14294-14299, 2016.

BERG, J. Tomorrow's earth. Science, Washington, v. 360, n. 6396, p. 1379, 2018. DOI: https://doi. org/10.1126/science.aau5515

BROWN, L. R.; MITCHELL, J. Building a new economy. In: WORLDWATCH INSTITUTE (ed.). The state of the world 1998. New York: WW Norton, 1998. p. 168-187.

BRYANT, L.; CARVER, L.; BUTLER, C. D.; ANAGED, A. Climate change and family planning: leastdeveloped countries define the agenda. Bulletin of the World Health Organization, Geneva, v. 87, n. 11, p. 852-857, 2009. DOI: https://doi.org/10.2471/BLT.08.062562

BYBEE, R. W. Planet Earth in crisis: how should science educators respond? The American Biology Teacher, Reston, v. 53, n. 3, p. 146-153, 1991. 
CHAMIE, J. Robots: a solution to declining and aging populations? New York: Inter Press Service, 2017. Retrieved Oct 26, 2018 from http://www.ipsnews.net/2017/09/robots-solution-decliningaging-populations/

CLARK, W. C. Sustainability science: a room of its own. Proceedings of the National Academy of Sciences, Washington, v. 104, n. 6, p. 1737-1738, 2007. DOI: https://doi.org/10.1073/ pnas.0611291104

COUNCIL OF THE SUSTAINABLE DEVELOPMENT SOLUTIONS NETWORK. An action agenda for sustainable development: report for the UN secretary-general. [S.I.]: SDSN, 2013. Retrieved Apr. 26, 2020 from: https://unstats.un.org/unsd/broaderprogress/pdf/130613-SDSN-An-Action-Agenda-forSustainable-Development-FINAL.pdf

DALY, H. Steady-state economics. Washington: Island Press, 1991.

DIAMOND, J. Collapse: how societies choose to fail or survive. New York: Penguin, 2005.

EHRLICH, P. R.; EHRLICH, A. H. The population explosion. New York: Simon and Schuster, 1991.

ENGELMAN, R. Beyond sustainababble. In: WORLDWATCH INSTITUTE (ed.). State of the world 2013: is sustainability still possible? Washington: Island Press, 2013. p. 3-16.

ENGELMAN, R. Nine population strategies to stop short of 9 billion. In: WORLDWATCH INSTITUTE (ed.). State of the world 2012: moving toward sustainable prosperity. Washington: Island Press, 2012. p. 121-128.

ENGELMAN, R. Population and sustainability: can we avoid limiting the number of people? Scientific American, Washington, v. 19, n. 2, p. 22-29, jun. 2009. DOI: https://doi.org/ doi:10.1038/ scientificamericanearth0609-22

ENGELMAN, R.; TAREFE, G.Y. Church, conservation, and family planning. In: ENGELMAN, R. et al. Family planning and environmental sustainability: assessing the science. Washington: Worldwatch Institute, 2016. p. 49-50.

ENGELMAN, R. et al. Family planning and environmental sustainability: assessing the science. Washington: Worldwatch Institute, 2016.

FINER, L. B.; ZOLNA, M. R. Declines in unintended pregnancy in the United States, 2008-2011. New England Journal of Medicine, Boston, v. 374, n. 9, p. 843-852, 2016. DOI: https://doi.org/10.1056/ NEJMsa1506575

FOLKE, C. Respecting planetary boundaries and reconnecting to the biosphere. In: WORLDWATCH INSTITUTE (ed.). State of the world 2013: is sustainability still possible? Washington: Island Press, 2013. p. 19-27.

FRANCIS, HOLY FATHER. Encyclical letter "Laudato Si": on care for our common home. 2015. Retrieved Apr. 26, 2020 from: http://www.vatican.va/content/dam/francesco/pdf/encyclicals/documents/ papa-francesco_20150524_enciclica-laudato-si_en.pdf

FREY, C. B.; OSBORNE, M. A. The future of employment: how susceptible are jobs to computerisation? Technological Forecasting and Social Change, New York, v. 114, p. 254-280, 2017. DOI: https://doi. org/10.1016/j.techfore.2016.08.019

GELL-MAN, M. Visions of a sustainable world. Engineering \& Science, v. 55, n. 3, p. 5-10, 1992. Retrieved Apr. 26, 2020 from: http://calteches.library.caltech.edu/3710/1/Mann.pdf 
GIL-PÉREZ, D.; VILCHES, A. Educación para la sostenibilidad y educación en derechos humanos: dos campos que deben vincularse. Teoría de la Educación: revista interuniversitaria, Salamanca, v. 29, n. 1, p. 79-100, 2017. Retrieved Oct 26, 2018 from https://revistas.usal.es/index.php/1130-3743/article/ view/16700

GIL-PÉREZ, D.; VILCHES, A.; EDWARDS, M.; PRAIA, J.; MARQUES, L.; OLIVEIRA, T. A proposal to enrich teachers' perception of the state of the world: first results. Environmental Education Research, Abingdon, v. 9, n. 1, p. 67-90, 2003. DOI: https://doi.org/10.1080/13504620303465

GHISELLINI, P.; CIALANI, C.; ULCIATI, S. A review on circular economy: the expected transition to a balanced interplay of environmental and economic systems. Journal of Cleaner Production, Amsterdam, v. 114, p. 11-32, 2016. DOI: https://doi.org/10.1016/j.jclepro.2015.09.007

HARARI, Y. N. Sapiens: a brief history of humankind. New York: Harper Collins, 2011.

KATES, R. W.; PARRIS, T. M. Long-term trends and a sustainability transition. Proceedings of the National Academy of Sciences, Washington, v. 100, n. 14, p. 8062-8067, 2003. DOI: https://doi. org/10.1073/pnas.1231331100

KATES, R. W. et al. Sustainability science. Science, Washington, v. 292, n. 5517, p. 641-64, 2001.

KOLLODGE, R. (ed.). State of the world population 2018: the power of choice - reproductive rights and the demographic transition. New York: UN, 2018.

KOMIYAMA, H.; TAKEUCHI, K. Sustainability science: building a new discipline. Sustainability Science, Dordrecht, v. 1, p. 1-6, 2006. DOI: https://doi.org/10.1007/s11625-006-0007-4

MAALUF, A. Le dérèglement du monde: quand nos civilisations s'épuisent. Paris: Grasset \& Fasquelle, 2009.

MARQUES, L.; VILCHES, A.; GIL-PÉRES, D.; PRAIA, J.; THOMPSON, D. The current planetary crisis: a missing dimension in science education. In: AZEITEIRO, U. M. et al. (ed.). Science and environmental education: towards the integrations of science education, experimental science activities and environmental education. Frankfurt: Peter Lang, 2008. p. 25-47.

MAYOR, F.; BINDE, J. The world ahead: our future on the making. Paris: UNESCO, 2000.

NORMANDER, B. Biodiversity: combating the sixth mass extinction. In: WORLDWATCH INSTITUTE (ed.). State of the world 2012: moving toward sustainable prosperity. Washington: Worldwatch Institute, 2012. p.169-186.

NOVO, M. El desarrollo sostenible: su dimensión ambiental y educativa. Madrid: Unesco: Pearson, 2006.

O'MEARA, M. Exploring a new vision for cities. In: WORLDWATCH INSTITUTE (ed.). The state of the world 1999. Washington: Worldwatch Institute, 1999. p. 133-150.

OSTERHAMMEL, J. The transformation of the world: a global history of the nineteenth century. Princeton: Princeton University Press, 2014.

POSCHEN, P. Decent work, green jobs and the sustainable economy. Sheffield: Greenleaf Publishing, 2015.

PRINCEN, T.; MANNO, J. P.; MARTIN, P. Keep them in the ground: ending the fossil fuel era. In: WORLDWATCH INSTITUTE (ed.). State of the world 2013: is sustainability still possible? Washington: Island Press, 2013. p. 161-171. 
ROBINSON, W. C. Population and sustainability. Resources for the Future, Washington, n. 182, 2013. Retrieved Oct 26, 2018 from http://www.rff.org/research/publications/population-andsustainability

SACHS, J. Common wealth: economics for a crowded planet. London: Penguin, 2003.

TAKEUCHI, K.; OSAMU, S.; LAHOTI, S.; GONDOR, D. Growing up: 10 years of publishing sustainability science research. Sustainability Science, Dordrecht, v. 12, p. 849-854, 2017.

UNITED NATIONS. Sustainable development goals. [S.I.]: UN, [2020]. Retrieved Apr. 20, 2020 from: https://www.un.org/sustainabledevelopment/sustainable-development-goals/

VILCHES, A.; GIL-PÉREZ, D. La ciencia de la sostenibilidad: una necesaria revolución científica. Ciência \& Educação, Bauru, v. 22, n. 1, p. 1-6, 2016a. DOI: https://doi.org/10.1590/1516-731320160010001

VILCHES, A.; GIL-PÉREZ, D. La transición a la sostenibilidad como objetivo urgente para la superación de la crisis sistémica actual. Revista Eureka sobre Enseñanza y Divulgación de las Ciencias, Cádiz, v. 13, n. 2, p. 395-407, 2016b. Retrieved Apr. 26, 2020 from: https://revistas.uca.es/index.php/eureka/ article/view/2975

VITOUSEK, P. M.; MOONEY, H. A.; LUBCHENCO, J.; MELILLO, J. M. Human domination of Earth's ecosystems. Science, Washington, v. 277, n. 5325, p. 494-499, 1997.

WEISS, K.R. Convince them to say it. In: ENGELMAN, R. et al. Family planning and environmental sustainability: assessing the science. Washington: Worldwatch Institute, 2016. p. 39-41. Retrieved Apr. 26, 2020 from: http://fpesa.net/wp-content/uploads/2016/06/16-118_WW_FPESAReportworking-links.pdf

WORLD COMMISSION ON ENVIRONMENT AND DEVELOPMENT. Our common future. Oxford: Oxford University Press, 1987.

WORLDWATCH INSTITUTE. State of the world 2016: can a city be sustainable? Washington: Island Press, 2016. 